\section{Fumigation of Empty Fruit Bins with Carbon Dioxide to Control Diapausing Codling Moth Larvae and Penicillium expansum Link. ex Thom Spores}

\author{
J.E. Cossentine, P.L. Sholberg, L.B.J. Jensen, K.E. Bedford, and \\ T.C. Shephard \\ Agriculture and Agri-Food Canada, PARC, Summerland, BC, Canada \\ $\mathrm{VOH} 1 \mathrm{ZO}$ \\ Additional index words. carbon dioxide, fumigation, codling moth, Cydia pomonella, \\ Botrytis cinerea
}

\begin{abstract}
Wooden fruit bins are a source of diapausing codling moth and postharvest pathogenic fungi. The redistribution of codling moths within bins is a problem where codling moth populations are being controlled by areawide codling moth sterile release programs, mating disruption programs, or both. Laboratory and fumigation chamber trials were carried out to determine the impact of relatively low levels of carbon dioxide on late-instar codling moth (Cydia pomonella $\mathrm{L}$.) and two postharvest fruit pathogens, Penicillium expansum Link ex Thom and Botrytis cinerea Pers. ex Fr. Fumigation of diapausing codling moth with $40 \% \mathrm{CO}_{2}$ in laboratory trials resulted in over $60 \%$ mortality after only 6 days of exposure and mortality increased with time of exposure. Significant mortality $(68 \%)$ of diapausing codling moth larvae occurred after 14 days of exposure in the laboratory to $13 \% \mathrm{CO}_{2}$ and a mean of $88 \%$ mortality was recorded after fumigation for 20 days. A significant number of $P$. expansum (46\%) spores failed to germinate after laboratory exposure to $13 \% \mathrm{CO}_{2}$ for 12 and 18 days respectively. Close to $100 \%$ of the $P$. expansum spores failed to germinate by day 20 . When diapausing codling moth larvae and spores from both plant pathogens were placed in wooden fruit bins and fumigated for 21 days at $13 \% \mathrm{CO}_{2}, 75 \%$ of the diapausing codling moths died and $80 \%$ of the $P$. expansum spores failed to germinate. No effect on $B$. cinerea was observed.
\end{abstract}

In apple orchards in the Pacific Northwest, late-instar codling moth, Cydia pomonella $\mathrm{L}$. (Lepidoptera: Tortricidae) larvae overwinter in a state of diapause in crevices of the tree bark. The larvae can also be found diapausing within the seams of wooden fruit bins that are used to hold harvested fruit (Higbee et al., 2001; Newcomer 1933; Proverbs and Newton 1975). Codling moth larvae are subsequently inadvertently moved out of the orchards with the fruit bins when they are transported to the packing houses and are redistributed back into orchards in the following season. This problem of redistributing codling moth into orchards has become an issue where codling moth populations are being controlled with an areawide sterile codling moth release program, mating disruption programs, or both. These techniques require low population densities to achieve successful economic control of the pest (Judd et al., 1997; Proverbs, 1982).

Postharvest pathogenic fungi also contaminate fruit bins and sanitation procedures are recommended before the bins are redistributed

Received for publication 14Aug. 2002. Accepted for publication 5 May 2003. This research was partially funded by the British Columbia Fruit Growers Association and British Columbia Investment Agriculture Foundation. We appreciate the technical assistance of H. Esson and M. Walker (Agriculture and Agri-Food Canada, Summerland, B.C.) and the loan of equipment by PraxAir Canada, Inc. (Delta, B.C.). to orchards and filled with fruit (Spotts et al., 1988). Elevated carbon dioxide $\left(\mathrm{CO}_{2}\right)$ has been documented as suppressing the growth and/or spore-germination of some postharvest fruit pathogens (El-Goorani and Sommer, 1981). Fumigation with $65 \%$ and $95 \% \mathrm{CO}_{2}$ has been demonstrated to kill diapausing and nondiapausing codling moth larvae (Gaunce et al., 1982; Soderstrom et al., 1990). As $\mathrm{CO}_{2}$ is an environmental pollutant, it was the objective of this study to determine if fumigation of empty fruit bins with $\mathrm{CO}_{2}$, at lower levels than previously studied, could be used to control diapausing codling moth larvae and spores of two species of common postharvest fungal pathogens.

\section{Materials and Methods}

Laboratory bioassays. Codling moth. Lateinstar codling moth larvae were reared by the Okanagan-Kootenay Sterile Insect Release Program (Osoyoos, B.C.). To obtain diapausing larvae, the insects were reared under short day conditions [12-h light (L)/12-h dark (D)] and $26{ }^{\circ} \mathrm{C}$ light and $21{ }^{\circ} \mathrm{C}$ dark, allowed to spin-up in corrugated cardboard and stored at $15{ }^{\circ} \mathrm{C}(0-\mathrm{h} \mathrm{L}: 24-\mathrm{h} \mathrm{D})$ for 3 to 5 months (Bloem et al., 1997). For the trials, individual late-instar larvae (diapausing, nondiapausing, or both) were placed in a superficial groove drilled on the surface of a $15-\times 30-\times 30-\mathrm{mm}$ block of rough-cut spruce wood to simulate the environment of wooden bins. Two pieces of fiberglass screen were secured over the larvae and wood blocks were held at $15^{\circ} \mathrm{C}$. Twenty-four hours later, when the larvae were spun-up in silk, the outer screen was removed from each block. Only larvae appearing to be healthy were included in the test.

Twenty-five wood blocks with spun-up diapausing larvae were placed in each of 18 plastic containers (12 $\mathrm{cm}$ diameter) with a screw-on plastic top. Each container had an inlet to let in gas continuously through a plastic tube connected to a glass capillary tube. The containers were stacked in three groups of six. One group of six received air only. To compare the effect of different concentrations of $\mathrm{CO}_{2}$ on diapausing codling moth larvae, the other two groups of six received a mixture of compressed $\mathrm{CO}_{2}$ and air equating to $40 \% \pm$ $2 \%$ and $60 \% \pm 2 \% \mathrm{CO}_{2}$. One container per treatment was opened on each of days 5 through 10 . The blocks were unwrapped and the larval mortality assessed by probing the insect with a fine brush. Mortality was recorded if no movement was detected.

In a separate experiment to compare the impact of $13 \% \mathrm{CO}_{2}$ on diapausing and nondiapausing larvae, containers attached to air only each held 15 diapausing and 15 nondiapausing larvae. The other two groups of six containers were fumigated with a mixture of $\mathrm{CO}_{2}$ and air equating to $13 \% \pm 2 \% \mathrm{CO}_{2}$. Each container held 25 larvae. One group of six containers held diapausing larvae and one group of six containers held nondiapausing larvae. Mortality was determined on every other day from day 10 through 20.

Each of the above tests was replicated three times and the $\mathrm{CO}_{2}$ mix was checked daily by analysing samples in a gas chromatograph (Shimadzu GC 14-A, Shimadzu Corp., Kyoto, Japan). The relative humidity $(\mathrm{RH})$ recorded inside one of the round plastic containers at $40 \% \mathrm{CO}_{2}$ with a data logger (Hobo Pro Series Data Logger, Hobo H8, Onset Computer Corp., Pocasset, Mass.) during one laboratory trial was $20 \% \mathrm{RH}$. An analysis of variance (ANOVA) was carried out after arcsine transformation of the percentage mortality (SAS 1996).

Laboratory bioassays. Plant pathogens. Dialysis tubing was dipped in suspensions of Botrytis cinerea Pers. ex Fr. (isolate B-27) or Penicillium expansum Link ex Thom (isolate 982-2W) spores (Sholberg and Gaunce, 1995). Ten pieces of tubing were placed inside separate plastic 60-mm petri dishes, which were then sealed with Parafilm M (Pechiney Plastic Packaging, Menasha, Wisc.). The laboratory fumigation protocol was similar to that used for the codling moth larvae described above. One petri dish of each fungus species was placed in each of 18 plastic fumigation containers. One group of six containers received air only, one a mixture of air and $\mathrm{CO}_{2}$ that equated to $40 \% \pm 2 \% \mathrm{CO}_{2}$ and one $13 \% \pm$ $2 \% \mathrm{CO}_{2}$. Every other day from day 10 through 20 , the fungus-contaminated tubing was removed from one container per treatment. The dialysis tubing pieces from each petri dish were placed on prepared Potato Dextrose 
Agar (PDA) plates and incubated overnight at $20{ }^{\circ} \mathrm{C}$. The plates were inspected under a light microscope and the percentage of spore germination determined from two counts of $\approx 100$ spores each. The study was replicated twice over time. An ANOVA was carried out after arcsine transformation of the percentage of ungerminated spores (SAS 1996).

Bin trials. Codling moth. The technique used to position test codling moth larvae in wooden fruit bins was previously described (Cossentine et al., 2002). Strips of wood ( $7.5 \mathrm{~cm}$ wide) from the sides of dismantled wooden bins were cut at an angle to fit vertically, snugly against the side of an intact bin with one edge against the corner joint. On one side of the wooden strips, 20 superficial grooves were routed. On the day before each bin trial, one diapausing fifth-instar codling moth larva was placed in each groove. The surface of the wooden strip was covered with a fiberglass screen that was then stapled in place. The larvae were held at $15^{\circ} \mathrm{C}$ and left to spin a cocoon in the grooves for up to $24 \mathrm{~h}$ before they were moved to the fumigation chamber. The status of each larva as alive or dead was assessed and recorded before a wooden strip was screwed (larvae inward) snugly into each of two opposite corners of fruit bins to be treated. In this manner, each treated bin carried up to 40 sentinel diapausing or nondiapausing codling moth larvae.

Three nested bins (one on the bottom, one on its side inside the bottom bin, and one flipped upside down on top of the middle bin) were placed inside a $26-\mathrm{m}^{3}$ fumigation chamber directly on a cement floor. A data logger (Hobo Pro Series Data Logger, Hobo H8, Onset Computer Corp., Pocasset, Mass.) was placed on the top bin to record temperature and humidity over time. Two compressed gas cylinders, each containing $\approx 65 \mathrm{~kg} \mathrm{CO}$, were partially opened inside the fumigation chamber before the door was sealed. Releasing compressed gas into the fumigation chamber prior to sealing it was necessary to get the concentration of $\mathrm{CO}_{2}$ above $20 \%$ within $24 \mathrm{~h}$. After $\approx 1 \mathrm{~h}$, a continuous supply of $\mathrm{CO}_{2}$ from a compressed gas cylinder was channelled into the chamber. The bins were fumigated for $14 \mathrm{~d}$. Fans continuously circulated the air within the chamber. The level of the $\mathrm{CO}_{2}$ was monitored throughout the 2 -week period. The initial concentration of $\mathrm{CO}_{2}$ began near $55 \% \pm$ $1 \% \mathrm{CO}_{2}$ and settled to $\approx 25 \% \pm 2 \% \mathrm{CO}_{2}$ after $1 \mathrm{~d}$. In the second replication, an automatic gas monitor and controller (Servomex 1370, Servomex Group Ltd., Crowborough, East Sussex, England) was attached to a compressed gas cylinder leading into the fumigation chamber to maintain the concentration of $\mathrm{CO}_{2}$ at $25 \%$ after the initial reading of $51.5 \%$. A feed line from the chamber fed back to the monitor to measure and regulate the flow of the $\mathrm{CO}_{2}$. The accuracy of the monitor was checked by analysing samples using a gas chromatograph (Shimadzu GC 14-A, Shimadzu Corp., Kyoto, Japan). Three nested bins each containing 40 codling moth larvae positioned as described above, were similarly sealed in a control chamber. The temperature in both chambers was maintained at $15{ }^{\circ} \mathrm{C}$. After $14 \mathrm{~d}$, each wooden strip was unscrewed and larval mortality assessed.

The same protocol was used for a second study when a gas monitor (Servomex 1370, Servomex Group) was used to expose the bins to $13 \% \mathrm{CO}_{2}$ for $21 \mathrm{~d}$. Because the concentration required in this trial was $<20 \%, \mathrm{CO}_{2}$ was not released inside the chamber before sealing the fumigation chamber. Again, the study was repeated twice. An ANOVA was carried out after arcsine transformation of the percentage mortality. Treatment means were compared using Tukey's Studentized Range Test (SAS 1996).

Bin trials. Plant pathogens. Pieces of dialysis tubing were dipped in a suspension of $B$. cinerea Pers. ex Fr. or P. expansum Link. ex Thom spores. The contaminated pieces of tubing were placed in separate plastic $60-\mathrm{mm}$ petri dishes which were then sealed with Parafilm. Treatment was carried out during the codling moth trials using $13 \% \mathrm{CO}_{2}$ described above. One petri dish of each species was placed inside the stack of bins and one was placed on the top of the bins in both the fumigated and the control chambers. Spore germination was assessed post-treatment as described above. An ANOVA was carried out after arcsine transformation of the percentage of ungerminated spores. Treatment means were compared using Tukey's Studentized Range Test (SAS 1996).

\section{Results and Discussion}

Laboratory bioassays. Codling moth. Codling moth larvae that were killed by the $\mathrm{CO}_{2}$ in the fumigation trials appeared hard and desiccated. This is probably the result of the $\mathrm{CO}_{2}$ causing the insects' spiracles to open, resulting in excessive respiration (Hazelhoff, 1928). A reduced relative humidity (RH) resulting from the $\mathrm{CO}_{2}$ treatment may have also contributed to the desiccation of the larvae. The $\mathrm{CO}_{2}$ had a significant effect on codling moth mortality $(\mathrm{F}=292.21 ; \mathrm{df}=2 ; P<0.0001)$. Over $80 \%$ of the diapausing fifth-instar codling moth larvae were killed when exposed to either $60 \%$ or $40 \% \mathrm{CO}_{2}$ for more than $8 \mathrm{~d}$
(Fig. 1). Gaunce et al.(1982) documented that $95 \% \mathrm{CO}_{2}$ killed $100 \%$ of diapausing codling moth larvae within $48 \mathrm{~h}$ of exposure at $27^{\circ} \mathrm{C}$ and Soderstrom et al. (1990) reported $95 \%$ of diapausing codling moth larvae were killed with a $60 \% \mathrm{CO}_{2}$ atmosphere in 13 to $24 \mathrm{~d}$. Our results indicated that a high percentage of diapausing codling moth larvae could be killed at $40 \% \mathrm{CO}_{2}$ and, as expected, that the mortality generally increased with the length of exposure.

When diapausing and nondiapausing codling moth were simultaneously exposed to $13 \% \mathrm{CO}_{2}$, significant mortality $(\mathrm{F}=96.53$; df $=1 ; P<0.0001)$ of larvae from both diapausing conditions was recorded after $14 \mathrm{~d}$ of exposure. The effect of the diapausing state of the larvae was significant $(\mathrm{F}=5.41 ; \mathrm{df}=1$; $P=0.0235)$ and high mortality of nondiapausing larvae occurred earlier than was recorded for the diapausing larvae (Fig. 2). Soderstrom et al.(1990) also observed that the diapausing codling moth larval stage was the most difficult stage to control with $\mathrm{CO}_{2}$. However, in our experiments even at the low level of $13 \%$ $\mathrm{CO}_{2}$, a mean of $87.7 \%$ [standard error $(\mathrm{SE})=$ 4.3] of the diapausing codling moth larvae were killed after $20 \mathrm{~d}$ of fumigation.

Laboratory bioassays. Plant pathogens. High levels of $\mathrm{CO}_{2}$ are believed to suppress fungi by reducing the rate of various metabolicfunctions resulting in lowered respiration (Sommer 1985). Significantly $(P<0.0001)$ more of the $P$. expansum spores failed to germinate after exposure to $13 \%$ and $40 \%$ $\mathrm{CO}_{2}$ compared with the control after 12 or more days of treatment (Fig. 3). After $20 \mathrm{~d}$ of exposure to either $\mathrm{CO}_{2}$ concentration, close to $100 \%$ of the P. expansum spores failed to germinate. The $\mathrm{CO}_{2}$ had less effect on the $B$. cinerea, and germination of the spores exposed to $13 \%$, and $40 \% \mathrm{CO}_{2}$ was not significantly $(P<0.05)$ less than the controls until days 18 and 20 (Fig. 4). The Parafilm may have decreased the concentration of the $\mathrm{CO}_{2}$ reaching the spores $\left(\mathrm{CO}_{2}\right.$ permeability: $400 \mathrm{cc} / \mathrm{m}^{2} / 24 \mathrm{~h}$ at $23{ }^{\circ} \mathrm{C}$ and $\left.80 \% \mathrm{RH}\right)$.

Bin trials. Codling moth. After releasing compressed gas into the fumigation chamber prior to sealing it, the concentration decreased

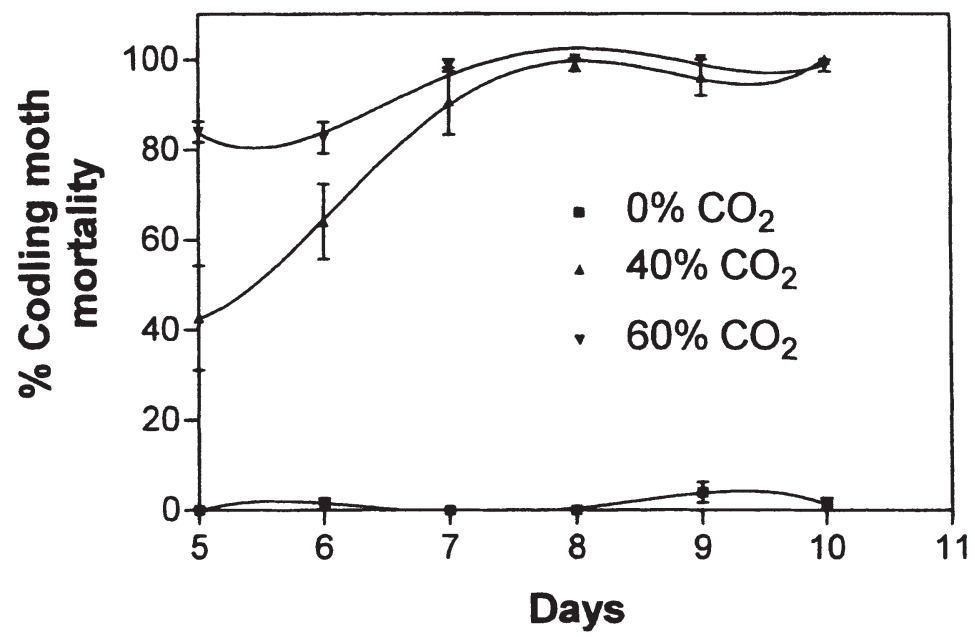

Fig. 1. Mean percent diapausing fifth-instar codling moth mortality $(n=25)$ after 5 to $10 \mathrm{~d}$ of exposure to $0 \%$, $40 \%$, or $60 \% \mathrm{CO}_{2}$. Tests were replicated three times. Bar represents the standard error of the mean. 


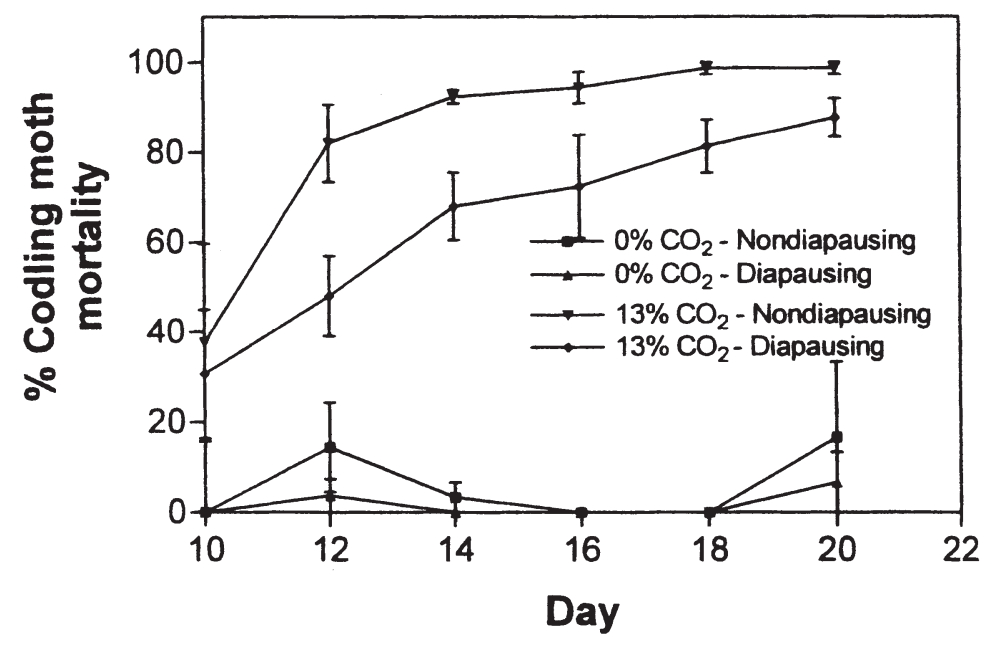

Fig. 2. Mean percent diapausing and nondiapausing fifth-instar codling moth mortality after 10 to $20 \mathrm{~d}$ of exposure to $0 \%$ or $13 \%$ carbon dioxide. In $\mathrm{CO}_{2}$ treatments $\mathrm{n}=25$ larvae; in control $\mathrm{n}=15$. Tests were replicated three times. Bars represents the standard error of the mean.

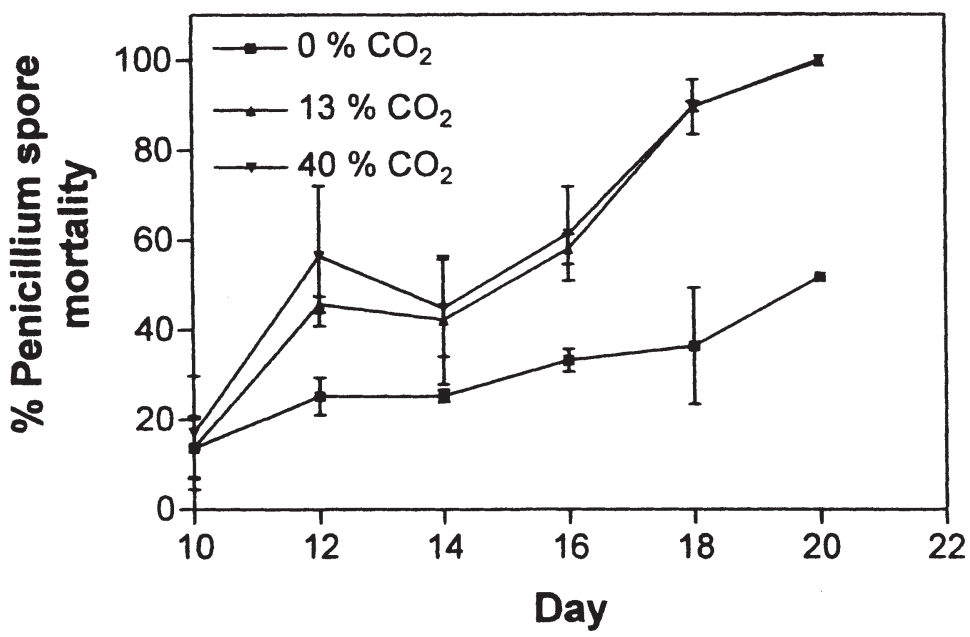

Fig. 3. Mean percent mortality of Penicillium expansum spores after 10 to $20 \mathrm{~d}$ of exposure to $0 \%, 13 \%$, or $40 \%$ carbon dioxide. $\mathrm{N}=10$ samples of spores $/ \mathrm{CO}_{2}$ treatment. Tests were replicated twice.

from $50 \% \pm 1 \%$ to $25 \% \pm 1 \% \mathrm{CO}_{2}$ in $1 \mathrm{~d}$. A mean of $95 \%$ ( $\mathrm{SE}=3.4$ ) of the diapausing codling moth larvae were killed after $14 \mathrm{~d}$ of exposure to this fumigation treatment in the first trial and a mean of $78.3 \%(\mathrm{SE}=5.1)$ in the second trial. In both trials, as well as in the mean of the two (Table 1), the mortality was significantly higher in the fumigated chamber than in the control (mean data: $\mathrm{F}=217.42$, df $=1, P<0.0001)$. There was no significant effect of the location of the bin (bottom, middle, or top) on codling moth mortality (mean data: $\mathrm{F}=0.22$, df $=2, P=0.8046$ ). The $\mathrm{RH}$ in the first trial ranged from $25 \%$ to $43 \% \mathrm{RH}$ and in the second trial it ranged from $34 \%$ to $43 \% \mathrm{RH}$ over the $14 \mathrm{~d}$ of treatment. The slightly higher RH in the second trial may account for the lower codling moth mortality.
Soderstrom et al. (1990) noted that lower RH $\left(60 \%\right.$ vs. $95 \%$ ) decreased the $\mathrm{LT}_{50}$ of the $\mathrm{CO}_{2}$ for codling moth larvae.

A larger difference in mortality was observed between the two trials of the bin trials exposing nondiapausing and diapausing larvae to $13 \% \mathrm{CO}_{2}$. In both trials, significantly more codling moth larvae died in the chamber fumigated with $\mathrm{CO}_{2}$ vs. the control (mean data: $\mathrm{F}=281.76$, df $=1, P<0.0001)$. There was no significant difference in the percentage of the diapausing and nondiapausing larvae killed $(\mathrm{F}=0.23, \mathrm{df}=1, P=0.6354)$, nor was there any significant effect of the location of the bin (bottom, middle, or top) on codling moth mortality $(\mathrm{F}=0.27, \mathrm{df}=2, P=0.7654)$. However in the first trial, a mean of only $59.5 \%$ $(\mathrm{SE}=7.8)$ of the diapausing larvae died and in the second trial a mean of $89.6 \%(\mathrm{SE}=3.9)$ of the larvae died over the $21 \mathrm{~d}$ of treatment (Table 1). In the first trial of the $13 \% \mathrm{CO}_{2}$ bin trial, the $\mathrm{RH}$ ranged from $75 \%$ to $55 \%$ $\mathrm{RH}(70 \%$ to $55 \% \mathrm{RH}$ in the control chamber). Unfortunately the data logger, although placed in the chamber before treatment, did not function in the second trial (55\% to $45 \%$ $\mathrm{RH}$ in the control chamber).

Bin trials. Plant pathogens. Significantly $(P<0.0001)$ low $P$. expansum spore germination was recorded in both replications of the bin trials with a mean of $80.2 \%(\mathrm{SE}=3.8)$ failing to germinate (Table 2). This large reduction in spore germination could reduce postharvest decay (Spotts, 1986). Although the amount of inoculum contributed by field bins to the spore load in drench solutions and dump tank water is unknown, bins are known to be a potentially significant source of inoculum (Sanderson and Spotts, 1995). In the second trial, none of the B. cinerea spores germinated in either the control or fumigation chambers. In this trial a new source of dialysis tubing had been used for suspending the spores and may have contained traces of an antimicrobial preservative even though washed to remove inhibitory chemicals.

It has been demonstrated in this study that $\mathrm{CO}_{2}$ has the potential to reduce numbers of diapausing codling moth larvae and P. expansum spore germination within wooden fruit bins at concentrations as low as $13 \%$. It is possible that both species can be controlled at lower $\mathrm{CO}_{2}$ concentrations, however, we could not
Table 1. Mean percentage of mortality of diapausing and nondiapausing fifth-instar codling moth positioned in empty fruit bins and fumigated with $0 \%, 13 \%$ or $25 \% \mathrm{CO}_{2} . \mathrm{N}=120$ larvae per replication.

\begin{tabular}{|c|c|c|c|}
\hline \multirow[b]{2}{*}{ Treatment } & \multicolumn{3}{|c|}{ Percentage of codling moth mortality (SE) } \\
\hline & Trial 1 & Trial 2 & Mean \\
\hline & \multicolumn{2}{|c|}{$25 \% \mathrm{CO}_{2}$} & \\
\hline $\begin{array}{l}\text { Control } \\
\text { diapausing }\end{array}$ & $0.00(0.00)$ & $3.41(2.30)$ & $1.71(1.21)$ \\
\hline $\begin{array}{c}\mathrm{CO}_{2} \text { treatment } \\
\text { diapausing }\end{array}$ & $95.00(3.42)$ & $78.29(5.08)$ & $86.64(3.86)$ \\
\hline \multicolumn{4}{|c|}{$13 \% \mathrm{CO}_{2}$} \\
\hline $\begin{array}{l}\text { Control } \\
\text { nondiapausing } \\
\text { diapausing }\end{array}$ & $\begin{array}{r}12.82(1.28) \\
6.53(3.05)\end{array}$ & $\begin{array}{l}0.93(0.93) \\
0.93(0.93)\end{array}$ & $\begin{array}{l}1.10(0.76) \\
4.19(1.84)\end{array}$ \\
\hline $\begin{array}{l}\mathrm{CO}_{2} \text { treatment } \\
\text { nondiapausing } \\
\text { diapausing }\end{array}$ & $\begin{array}{l}59.86(8.15) \\
59.48(7.79)\end{array}$ & $\begin{array}{l}95.53(2.33) \\
89.63(3.87)\end{array}$ & $\begin{array}{l}77.70(6.73) \\
74.55(6.15)\end{array}$ \\
\hline
\end{tabular}

Table 2. Mean percent mortality of Botrytis cinerea Pers. ex Fr. and Penicillium expansum Link ex Thom spores after fumigation in wooden fruit bins with $0 \%$ or $13 \% \mathrm{CO}_{2}$. ( $\mathrm{N}=10$ plates per species per replication each containing $\approx 200$ spores).

\begin{tabular}{lcccc}
\hline & \multicolumn{4}{c}{ Percentage of spore mortality (SE) } \\
\cline { 2 - 5 } Treatment & Trial 1 & Trial 2 & Mean & $\mathrm{P}>\mathrm{F}$ \\
\hline \multirow{5}{c}{ Penicillium } \\
Control & $23.60(2.14)$ & $14.44(3.07)$ & $19.26(2.08)$ & --- \\
$13 \% \mathrm{CO}_{2}$ & $68.35(4.83)$ & $92.00(2.13)$ & $80.18(3.76)$ & $<.0001$ \\
& \multicolumn{5}{c}{ Botrytis } \\
Control & $17.50(1.84)$ & $\mathrm{NA}^{\mathrm{z}}$ & $\mathrm{NA}$ & \\
$13 \% \mathrm{CO}_{2}$ & $22.40(1.49)$ & $\mathrm{NA}$ & $\mathrm{NA}$ & 0.5481 \\
\hline
\end{tabular}

${ }^{\mathrm{z}} 100 \%$ ungerminated spores in both the control and $13 \% \mathrm{CO}_{2}$ therefore considered dead before use.

${ }^{\mathrm{NA}}$ Not appropriate. 


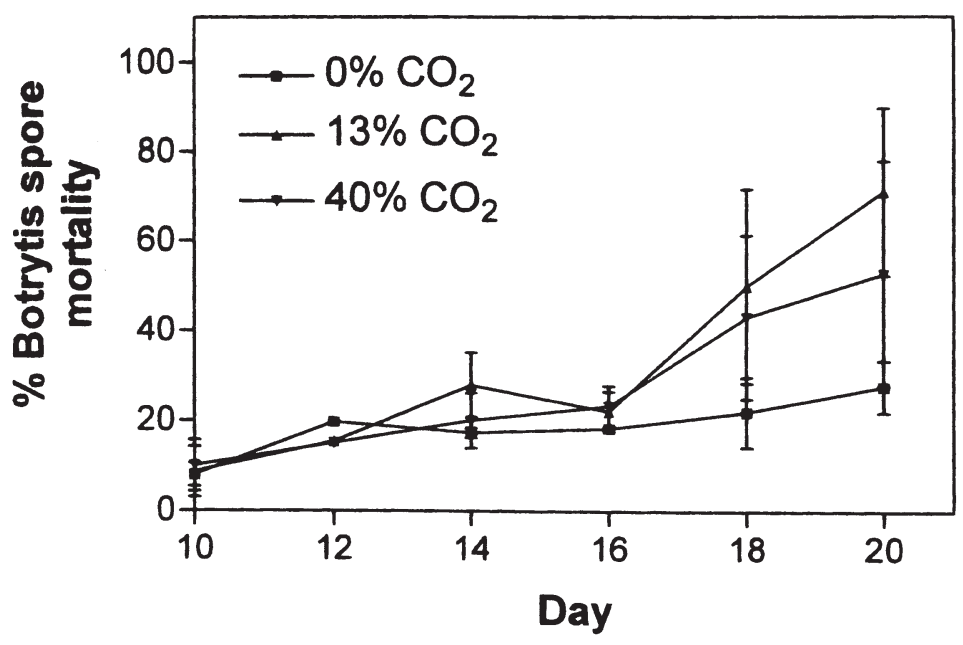

Fig. 4. Mean percent mortality of Botrytis cinerea spores after 10 to $20 \mathrm{~d}$ of exposure to $0 \%, 13 \%$, and $40 \%$ carbon dioxide. $\mathrm{N}=10$ samples of spores $/ \mathrm{CO}_{2}$ treatment. Tests were replicated twice. Data for day 12 represents only one replication as germination did not occur due to the use of inappropriate agar plates.

adequately monitor lower concentrations in the laboratory. Although increased $\mathrm{CO}_{2}$ levels $\left(40 \% \mathrm{CO}_{2}\right)$ did not significantly expedite the failure of $P$. expansum spores to germinate, fumigation with $40 \% \mathrm{CO}_{2}$ decreased the time required to achieve high codling moth mortality. However, as $\mathrm{CO}_{2}$ is an environmental pollutant, it would be more advantageous to use the lowest concentration of $\mathrm{CO}_{2}$ possible to obtain the control desired. The fumigation of empty fruit bins with low levels of $\mathrm{CO}_{2}$ may provide the fruit industry with a relatively economic and environmentally acceptable solution to two pest problems.

\section{Literature Cited}

Bloem, S., KA. Bloem, and L.S. Fielding. 1997. Mass-rearing and storing codling moth larvae in diapause: A novel approach to increase produc- tion for sterile insect release. J. Entomol. Soc. Brit. Columbia. 94:75-81.

Cossentine, J.E., L.B. Jensen, and L. Moyls. 2002. Fruit bins washed with Steinernema carpocapsa (Rhabditida:Steinernematidae) to control Cydia pomonella (Lepidoptera: Tortricidae). Biol. Control, Sci. and Technol. 12:251-258.

El-Goorani, M.A. and N.F. Sommer. 1981. Effects of modified atmospheres on postharvest pathogens of fruits and vegetables. Hort. Rev. 3:412-461.

Gaunce, A.P., C.V.G. Morgan, and M. Meheriuk. 1982. Control of tree fruit insects with modified environments, p. 383-390. In: D.G. Richardson and M. Meheriuk (eds.). Controlled atmospheres for storage and transport of perishable agricultural commodities. Symp. Ser. No. 1. Timber Press, Ore.

Hazelhoff, E.H. 1928. Carbon dioxide a chemical accelerating the penetration of respiratory insecticides into the tracheal system by keeping open the tracheal valves. J. Econ. Entomol. 21:790.

Higbee, B.S., C.O. Calkins, and C.A.Temple. 2001. Overwintering of codling moth (Lepidoptera: Tortricidae) larvae in apple harvest bins and subsequent moth emergence. J. Econ. Entomol. 94:1511-1517.

Judd, G.J.R., M.G.T. Gardiner, and D.R. Thomson. 1997. Control of codling moth in organicallymanaged apple orchards by combining pheromone-mediated mating disruption, postharvest fruit removal and tree banding. Entomolgia Experimentalis et Applicata 83:137-146.

Newcomer,E.J. 1933. Orchard insects of the Pacific Northwest and their control, U.S. Dept. Agr. Circ. 270.

Proverbs, M.D. 1982. Sterile insect technique in codling moth control, p. 85-99. In: Sterile insect technique and radiation in insect control. Proc. Intl. Atomic Energy Agency, Vienna 1981.

Proverbs, M.D. and J.R. Newton. 1975. Codling moth control by sterile insect release: Importation of fruit and fruit containers as a source of reinfestation. J. Entomol. Soc. Brit. Columbia 72:6-9.

Sanderson, P.G. and R. A. Spotts. 1995. Postharvest decay of winter and apple fruit caused by species of Penicillium. Phytopathology 85:103-110.

SAS Institute. 1996. SAS user's guide: Statistics, version 6.12 ed. SAS Inst., Cary, N.C.

Sholberg, P.L. and A.P. Gaunce. 1995. Fumigation of fruit with acetic acid to prevent postharvest decay. HortScience 30(6):1271-1275.

Soderstrom, E.L., D.G. Brandl, and B.B. Mackey. 1990. Responses of codling moth (Lepidoptera: Tortricidae) life stages to high carbon dioxide or low oxygen atmospheres. J. Econ. Entomol. 83:472-475.

Sommer, N. F. 1985. Role of controlled environments in suppression of postharvest diseases. Can. J. Plant Pathol. 7:331-339.

Spotts, R.A. 1986. Relationships between inoculum concentrations of three decay fungi and pear fruit decay. Plant Dis. 70:386-389.

Spotts, R.A., R.J. Holmes, and W.S. Washington. 1988. Sources of spores and inoculum concentrations related to postharvest decay of apple and pear. Australasian Plant Pathol. 17:48-52. 